\title{
602 大規模海洋構造物における犠牲陽極発生電流量の逆解析 Inverse Analysis of Sacrifice Electrode Current for Large-Scale Marine Structures
}

\author{
大野 弘樹 (東工大) 天谷 賢治(東工大) 大西 有希(東工大) \\ Hiroki OHNO, Tokyo Institute of Technology 2-12-10-okayama, Meguro-ku, Tokyo, Japan 152-8552 \\ Kenji AMAYA, Tokyo Institute of Technology 2-12- IO-okayama, Meguro-ku, Tokyo, Japan 152-8552 \\ Yuki OHNISHI, Tokyo Institute of Technology 2-12-1O-okayama, Meguro-ku, Tokyo, Japan 152-8552
}

Key Words: Inverse Problems, Cathode Protection, Seaside Structure, Current, Potential, BEM, FEM

1. はじめに

平成 22 年竣工の羽田空港D滑走路は栈橋構造を有 しており大量の鋼材を使用している。これらの鋼構造 物は，篇しい腐食環境下にさらされるので，腐食対策 が十分になされることが大変重要である。またこれ こ らの腐食対策を長期間有効に機能させるためには，腐 食問題に対する効率の良い維持管理技術を早急に確立。 することが必要である。[1]

鋼製の栈橋は主に犠牲陽極により防食されている. 犠牲陽極の寿命は犠牲陽極からの電流に比例するので 犠牲陽極の電流を把握することは重要である。[2]-[8]

本研究では，大規模海洋構造物の実例として羽田空 港 $\mathrm{D}$ 滑走路島の栈橋を対象とし，図 1 に示すように比 較的容易に計測が実施できる海中の電位から犠牲陽極 の電流を同定する逆問題について検討する.

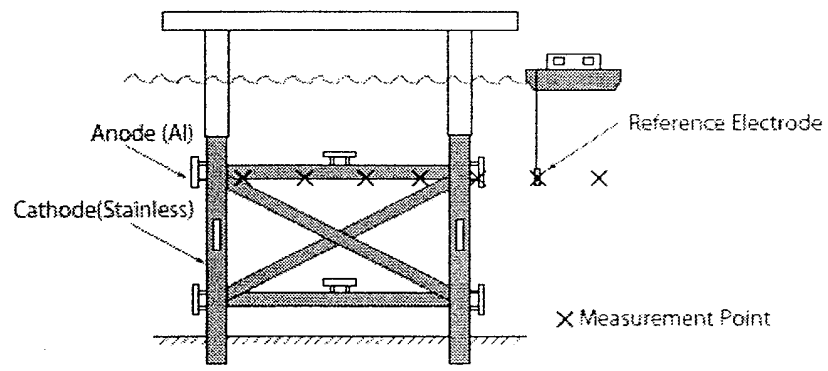

Fig.1 Inverse problem identifying currents on anodes from potential meseurements.

\section{2. 基礎式}

図 2 のように海水中の構造物周囲の海水が占める領 域を $\Omega$ とする。この領域の境界は, 構造物表面の境界 $\Gamma \mathrm{c}$ ，犠牲陽極表面の境界 $\Gamma \mathrm{a}$ ，また海水を仮想的に分 割した測定領域の境界 $\Gamma \mathrm{n}$ からなる。領域内の電位を $\phi$ とすると電位 $\phi$ は次式の Laplace 方程式を満足する.

$$
\nabla^{2} \phi=0
$$

境界条件は次式でモデル化する。

$$
\begin{array}{cl}
i_{a} \text { : 未知 } & \Gamma_{a} \text { 上 } \\
\phi=-R i+\phi_{c} & \Gamma_{c} \text { 上 } \\
i=0 & \Gamma_{n} \text { 上 }
\end{array}
$$

ここで， $\mathrm{R}$ は鋼材の表面抵抗， $\phi \mathrm{c}$ は鋼材の自然電位 であり，ia は犠牲陽極上の電流密度とする。また，犠 牲陽極上の電流密度を一定として近似し，ひとつの犠 牲陽極の表面積および電流を Sa および la とし，Ia=Sa $\times$ ia と表すことにする.

本問題においては海水領域内の複数位置における電位 $\phi$ in の計測量から未知量であるアノードおよびカソー ド上の電流量 ia 执よび ic を同定する.観測方程式は次 式で与えられる.

$$
\left\{\phi_{i n}\right\}=[A]\left\{I_{a}\right\}+\{b\}
$$

ここで $\{\phi$ in $\}$ は計測した電位を成分とするべクトル, \{Ia \}は各犠牲陽極の電流量を成分とするべクトルであ

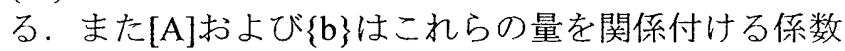
行列および定数べクトルであり，式(1)〜(4)を適当な数 值解析手法で離散化することにより求めることができ る.

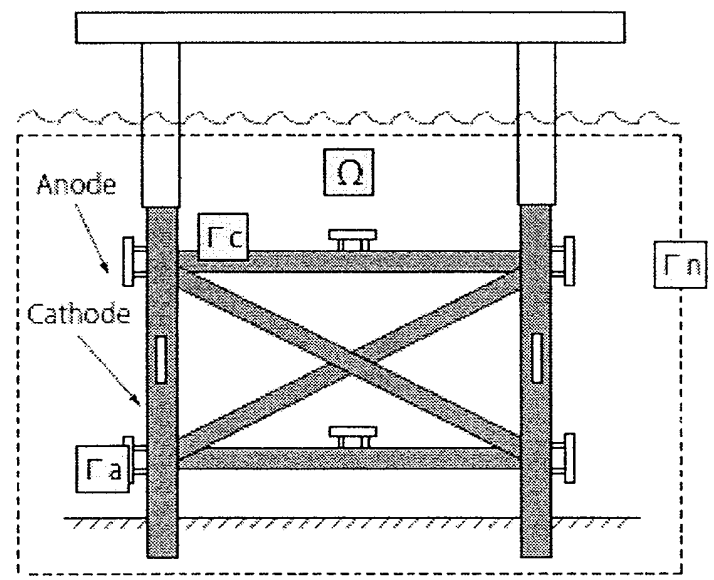

Fig.2 Domain for analysis and its boundary 本逆問題は計測值である\{申in\}から犠牲陽極の電流量 \{Ia $\}$ 同定する問題である。犠牲陽極の電流量は次式 のように求めることができる。

$$
\left\{I_{n}\right\}=[A]^{+}\left(\left\{\phi_{i n}\right\}-\{b\}\right)
$$


ここで $[A]^{+}$はムーアペンローズの一般逆行列をあらわ 寸

\section{3.解析領域の検討}

解析対象の栈橋構造物は幅 $500 \mathrm{~m}$ の大規模であるが， 電気的にすべてが短絡されている，犠牲陽極の電流の 変化や久落の影響が電気的にどのくらいの規模の領域 まで影響するかを把握することは重要である。本節で は境界要素法の電場解析を実施し，解析の規模を合理 的に決定する.

栈橋は図 1 に示すような杕構造の単位が維横格子状 にそれぞれ数十基づつ約 $30 \mathrm{~m}$ の水媣の海に並んだ構 造をしている。犠牲陽極が構成する大規模な電場を把 握するために境界要素法による 2 次元解析を実施した。

図 3 はこの栈橋構造のモデル化を表し，円内の搪大 図は一つの桁構造の単位を示している。実際の構造物 の鎙部と犠牲陽極の面積が等価になるように設定した。 図中赤丸で示した䇢所の横一列にある構造単位の犠牲 陽極を順に欠落させた境界条件を与え，赤丸で示した 領域の電位の変化を計算した。得られた電位を図 4 に 示す. 計測箘所の構造単位の番号は 6 番であり，欠落 箇所が自身の 6 番以外の構造単位にある場合にはほと んど電位変化が生じないことが分かる。すなわち，隣 の構造単位で犠牲陽極が欠落しても電位変化は生じな いことが確認できた。

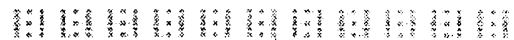

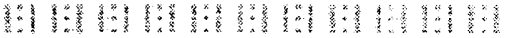

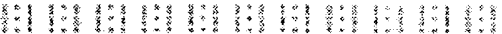

落1

*)

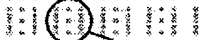

in

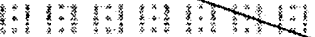

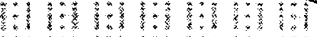

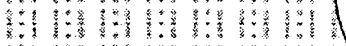

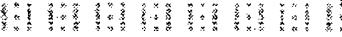

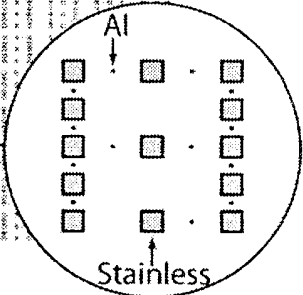

Fig.3 2D model of the claud of trass units

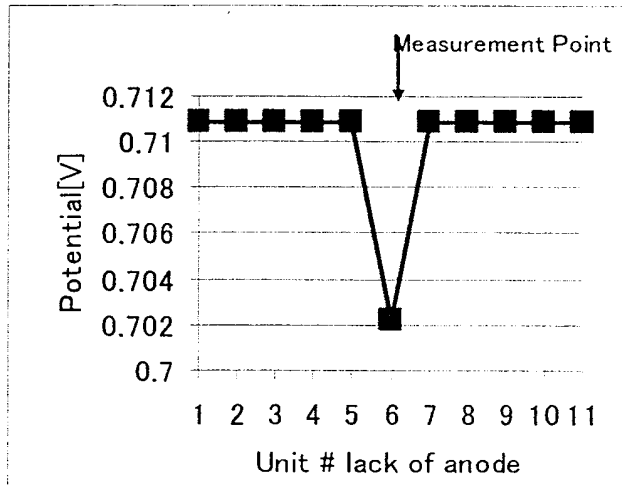

Fig.4 Potential change induced by lack of anode

\section{4.順解析例}

実際の栈橋単位構造を文献[1]を参考にして模した FEM モデルを用いて電場解析を実施し，犠牲陽極加ら の電流が構造物周囲の電位にどのように影響するかを 確認した。構造物表面の電位を図 3 および図 4 に示す.

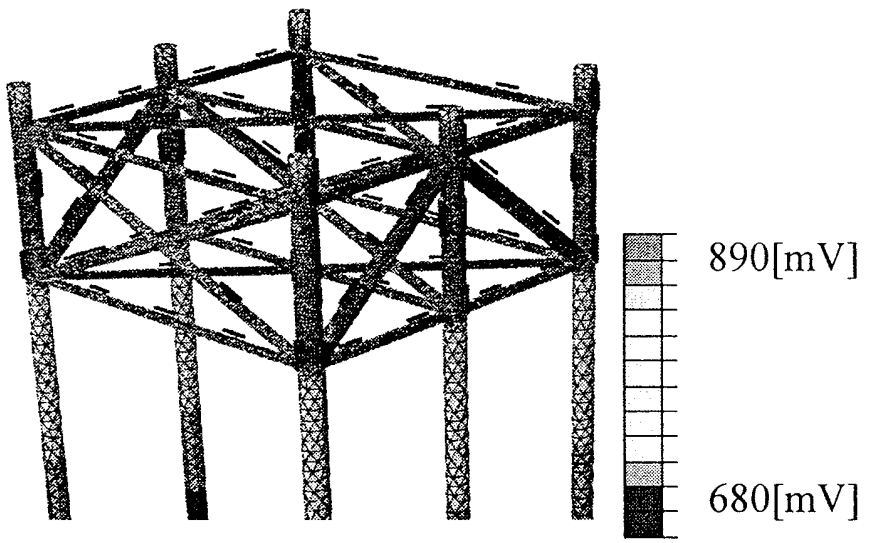

Fig.5 Potential distribution on the structure.

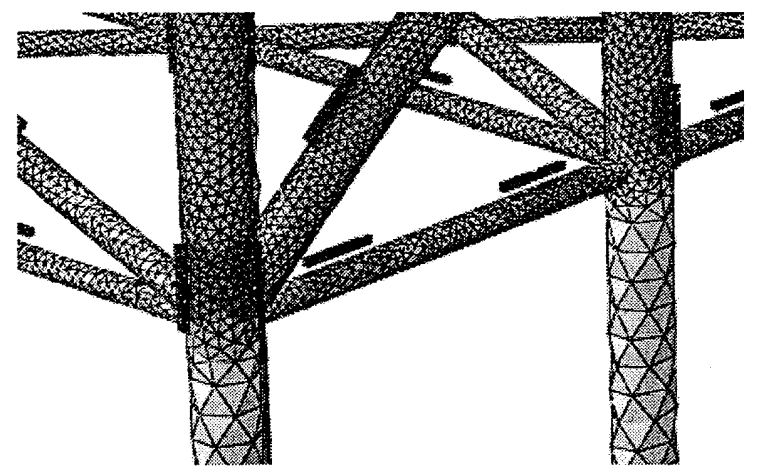

Fig.6 Close view of potential distribution on the structure.

\section{参考文献}

[1]Ishida M. 石田 雅巳「羽田空港再拡張事業-D滑走路 の鋼材の防食について」-日本鋼構造協会第 30 回鉄構 塗装技術討論会資料

[2] Nakayama, J., Amaya, K., Yamamoto, N. \& Terai, K., Development of monitoring method for coating condition inside ballast tank using numerical inverse analysis. Ziryo-to-Kankyo, 57, pp. 542, 547, 2008.

[3] Kishimoto, Y., Amaya, K., \& Hayabusa, K., Estimation Method of Copper Electroplating Current Densities by Inverse Analysis of Electric Potentials in Cells and Its Experimental Verification

[4] 青木繁，天谷賢治，宮坂松甫:”境界要素法による 腐食防食問題の解析”，裳華房,(1998).

[5] 天谷賢治，成瀬直樹，青木繁，宮坂松甫：境界要素 法論文集, 15 (1998), 59 .

[6]青木繁，天谷賢治，鄉家一紀: 日本機械学会論文 集 A,62-599 (1996), 1741 .

[7]岸本喜久雄，天谷賢治，青木繁：日本機械学会論 文集 A,56-525 (1990), 1282. 